\title{
Groundwater Quality Appraisal in Southern Parts of Kaduna State, Nigeria
}

\author{
Eduvie Martin Obada ${ }^{1}$, Olaniyan Isaac Olade jo ${ }^{2, *}$ \\ ${ }^{1}$ National Water Resources Institute, Kaduna, Nigeria \\ ${ }^{2}$ Department of Physical Sciences, Ondo State University of Science and Technology, Okitipupa, Nigeria
}

\begin{abstract}
Assessment of groundwater quality from the rocks of the Basement Complex in the southern parts of Kaduna State, Nigeria was carried out. Forty samp les from boreholes, hand-dug wells and springs were collected during the dry and raining seas ons for chemical and bacteriological analyses. The essence of the study is to assess the quality and the portability of the groundwater using the World Health Organization (WHO) standards for drinking water. The results of the water samples analyses indicate a low total mineralization. However, results of some hand dug wells suggest that the water might have been contaminated due to human activities and closeness to pit latrines/soak-away and other domestic refuse dumps. The Piper's trilinear and Schoeller diagrams showed that the groundwater in the study area can be classified to be $\mathrm{Ca}-\mathrm{Na}-\mathrm{HCO}_{3}$ fresh water.
\end{abstract}

Keywo rds Groundwater Quality, Total Mineralization, Pollution Indicators, Water Chemistry

\section{Introduction}

In spite of the considerable investment of Government in Nigeria over the years in the provision of water for domestic, industrial and agricultural purposes, a large part of the population still does not have access to water of adequate quantity and quality. It is estimated that only $58 \%$ of the inhabitants of the urban and semi-urban areas of Nigeria and $39 \%$ of rural areas have access to potable water supply. In spite of these low figures, the average delivery to the urban population is only 32 litres per capita per day (lpcd) while the value for rural areas is 10 lpcd[1].

Kaduna State is located in the humid, wet-dry tropics, in the northern reaches of the Guinea Savannah. Geologically, the area under investigation lies within the Crystalline Complex. In the study area, the average rainfall is $1350 \mathrm{~mm}$ per annum, and is distributed within four to eight months, usually from March to October[2],[3].

The ever increasing demand for water, especially for domestic purpose, has led to widespread and very intensive search in all parts of Nigeria, especially in the Crystalline Complex where occurrences of groundwater are considered low and generally to be under the control of geological structures and weathered overburden. Most rural communities in southern parts of Kaduna State depend largely on groundwater through wells and boreholes for their

* Corresponding author:

dejoolaniyan@gmail.com (Olaniyan Isaac Oladejo)

Published online at http://journal.sapub.org/ajee

Copyright (C 2013 Scientific \& Academic Publishing. All Rights Reserved water needs, since most surface sources are more susceptible to pollution and are expensive to develop. In view of the importance of this source of water to the communities in the area, there is therefore the need to assess the water chemistry and bacteriological characteristics of the groundwater in the area. The present research is also aimed at detecting localities with good water quality and also comparing present results with available water quality data carried out within the project area over a period of time.

\section{The Study Area}

The study area, southern parts of Kaduna State in the Northern Nigeria, covers about 24,500 square kilo meters and lies between latitudes $9^{\circ} 00^{\prime}-10^{\circ} 45^{\prime} \mathrm{N}$ and longitudes $7^{\circ} 10^{\prime}$ $8^{\circ} 45^{\prime} \mathrm{E}$. The area has boundaries with Niger State to the west, Federal Capital Territory (FCT) and Plateau State to the South and South-east, respectively, while Kano and Bauchi States have borders to the east of the study area (Figure 1).

\section{Geology and Hydrogeology}

The southern parts of Kaduna in the north-central Nigeria forms a part of the West African Mobile zone which extends from east to west from Nigeria, and Ghana where it is "sutured" to the West African craton by the Pan African Dahomeyan (or Beninian) belt. The whole ensemble of rocks in this zone had undergone an extensive episode of "remobilisation and reactivation" during the Pan-African thermotectonic event some 600 my ago[4]. 
The entire land area is underlain by Precambrian migmatite-gneiss complex, metasediments/metavolcanics (mostly schists, quartzite, and banded iron formations). Pan African granitoids and calc-alkaline granites, and volcanics of Jurassic age. These various rock units, especially the gneisses and the schists, have been affected by many periods of orogenic movements, resulting in extensive deformation and migmatization. McCurry[5] reported that the oldest rocks of the area are the gneisses and older metasediments believed to be Birrimian in age (about 2500 my).

The groundwater prospects of Basement areas have mixed reviews in the literature. The igneous and metamorphic rocks constituting the Basement Complex of Nigeria as a whole has an undeserved reputation as poor aquifers [6],[7].

Groundwater occurrence in the area could be grouped into three. These are:

(a) The Weathered/Fractured Basement Complex

(b) The Newer Basalts

(c) The River Alluvium

The weathered granular sandy zone is composed of coarse-grained sands, which form a level below the loose clayey laterite. The granular sands may consist of sands or gravels derived from the disintegrations of the crystalline rock. There are good prospects for groundwater production in the horizon of the intermediate zones with an average thickness of about $6 \mathrm{~m}$ [8]. The majority of hand-dug wells in the study area terminate in this part of the zone.

The Newer Basalts occur in the vicinity of Kafanchan and Manchok along the western edge of the Jos Plateau. The Basalts were erupted after the Plateau had achieved almost its present-day topography and are themselves little affected by erosion[5]. Thus, they often overlie alluvial deposits. Zones of weathering and beds of alluvium also occur between individual basalt flows. The aquifer potential of the fluvio-volcanic sequence is good and yields of 370 to 500 $\mathrm{m}^{3} / \mathrm{d}$ have been obtained. Also, a borehole (No. GW R/21/l) drilled at Tum village, within the Newer Basalts, produced a yield of $12.6 \mathrm{~m}^{3} / \mathrm{h}$. A highly productive spring (Kajim) emerges from the Newer Basalt at Manchok. The dry season flow of this spring is about $11,000 \mathrm{~m}^{3} / \mathrm{day}$ [9]. It forms the headwater of a tributary of the Kaduna River.

\section{Methodology}

Water samples collected from boreholes, hand dug wells and springs were subjected to water quality assessment during the study. The chemical elements, which are found in groundwater, come from rains, organic action in the soil and decomposition of minerals in the rocks through which the groundwater travels. The present research is aimed at detecting localities with good water quality and also comparing present results with available water quality data carried out within the project a rea over a period of time.

The chemical parameters that are the most essential in groundwater chemistry and present in important quantities which were analysed for include: major ions concentration (sodium, calcium, magnesium, potassium, bicarbonate, sulphate and chloride). To further achieve a better assessment of the water quality, nitrate and iron were also analysed for.

\section{Sampling and Chemical Analysis}

In the present study, two sets of sampling with a total of forty samples (boreholes, hand-dug wells and springs) were collected for chemical analysis. However, after subjecting the results to quality control by means of the ionic balance, nine (9) of the results were rejected due to error limit of over $10 \%$. The details of sample locations are shown in Figure 1. The temperature, $\mathrm{pH}$, specific conductance and bicarbonate were determined on the spot using Hach Kit and Kent $\mathrm{pH}$ meter to obtain accurate results because these properties change with time on exposure of the water sample to the atmosphere[10]. The major cations $\mathrm{Ca}^{++}, \mathrm{Na}^{+} \cdot \mathrm{K}^{+}$and $\mathrm{Mg}^{++}$ were acidified on the spot and taken to the laboratory for analysis using Atomic Absorption Spectrometer (AAS) and flame photometer, while the anions $\mathrm{Cl}^{-}, \mathrm{SO}_{4}{ }^{2-}, \mathrm{NO}_{3}{ }^{-}$were determined by titrimetrical method and calorimetric techniques.

Bacteriological analyses of hand-dug wells in parts of the study area were carried out in Mando and Kawo areas of Kaduna metropolis both during rainy and dry seasons. Faecal coliforms and faecal streptococcus were the indicator organisms analysed for during the research. Membrane filter technique was used and Eosin Methylene Blue (EMB) agar was the culture medium, while a temperature of $37^{\circ} \mathrm{C}$ was maintained and incubated for a period of 18-24 hours.

\section{Results and Discussions}

Tables 1 and 2 show the results of the physico-chemical analyses and the ionic balance of groundwater in the study area. The water samples have a low total mineralization as indicated from the conductivity values. The Piper's trilinear diagram (Figure 2) and Schoeller diagram showed that the groundwater in the study area can be said to be a $\mathrm{Ca}-\mathrm{Na}-\mathrm{HCO}_{3}{ }^{-}$fresh water. Generally, since the Basement rocks contain minerals such as feldspars, amphiboles, pyroxene, and micas, which contain various amounts of the elements, they are often released into groundwater when the minerals undergo weathering. Similar results have been obtained from Kaduna area[11] and central parts of northern Nigeria with similar geology[12].

The Sodium Adsorption Ratio (SA R), which indicates the extent to which soil adsorb sodium from water is influenced by the concentration and composition of the soluble salts. This parameter is important because, above certain levels, the adsorbed sodium has adverse effects upon the physical properties of the soil, namely, permeability and infiltration rates. All the water samples fall within the low regions of both salinity and sodium hazard areas. 


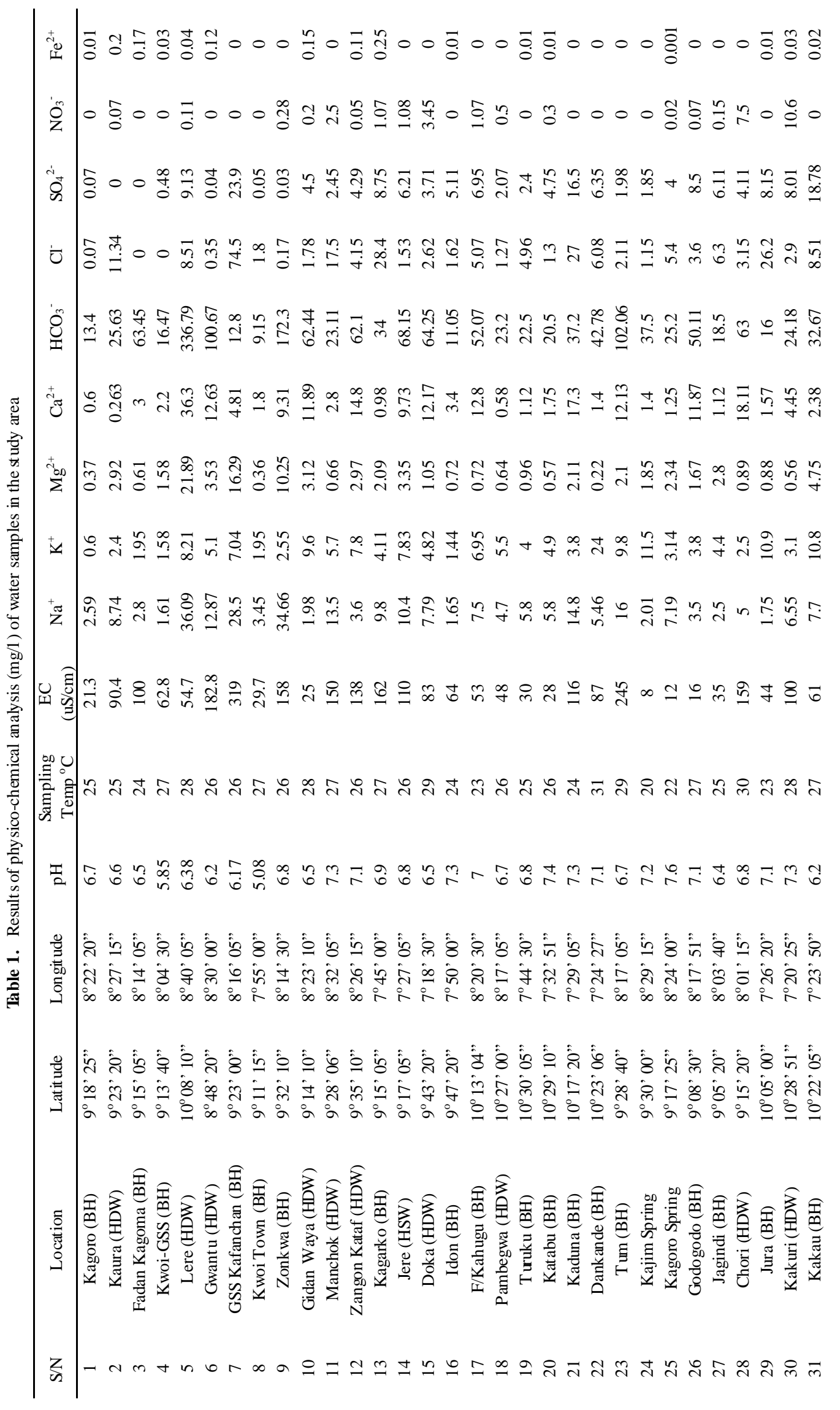




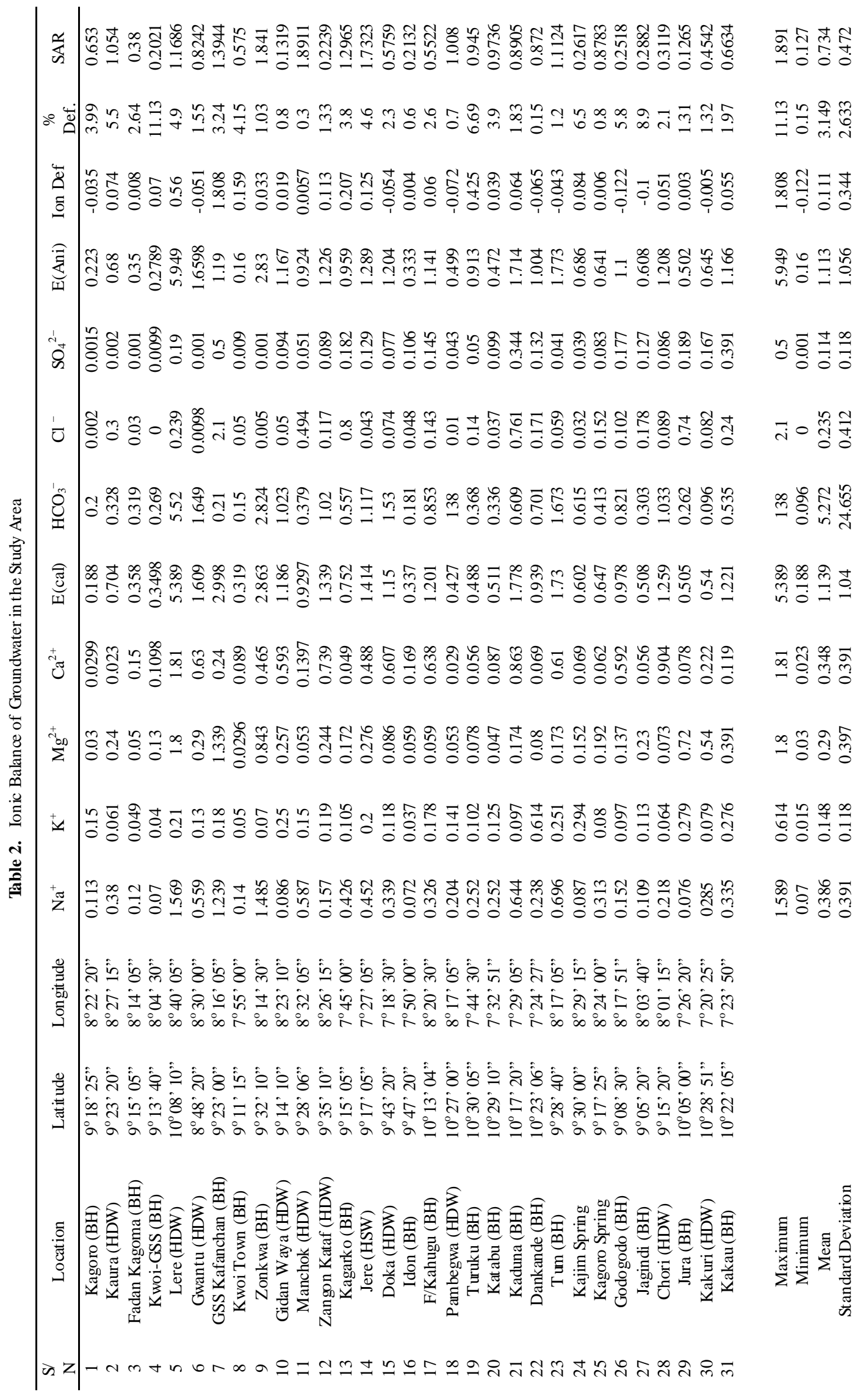




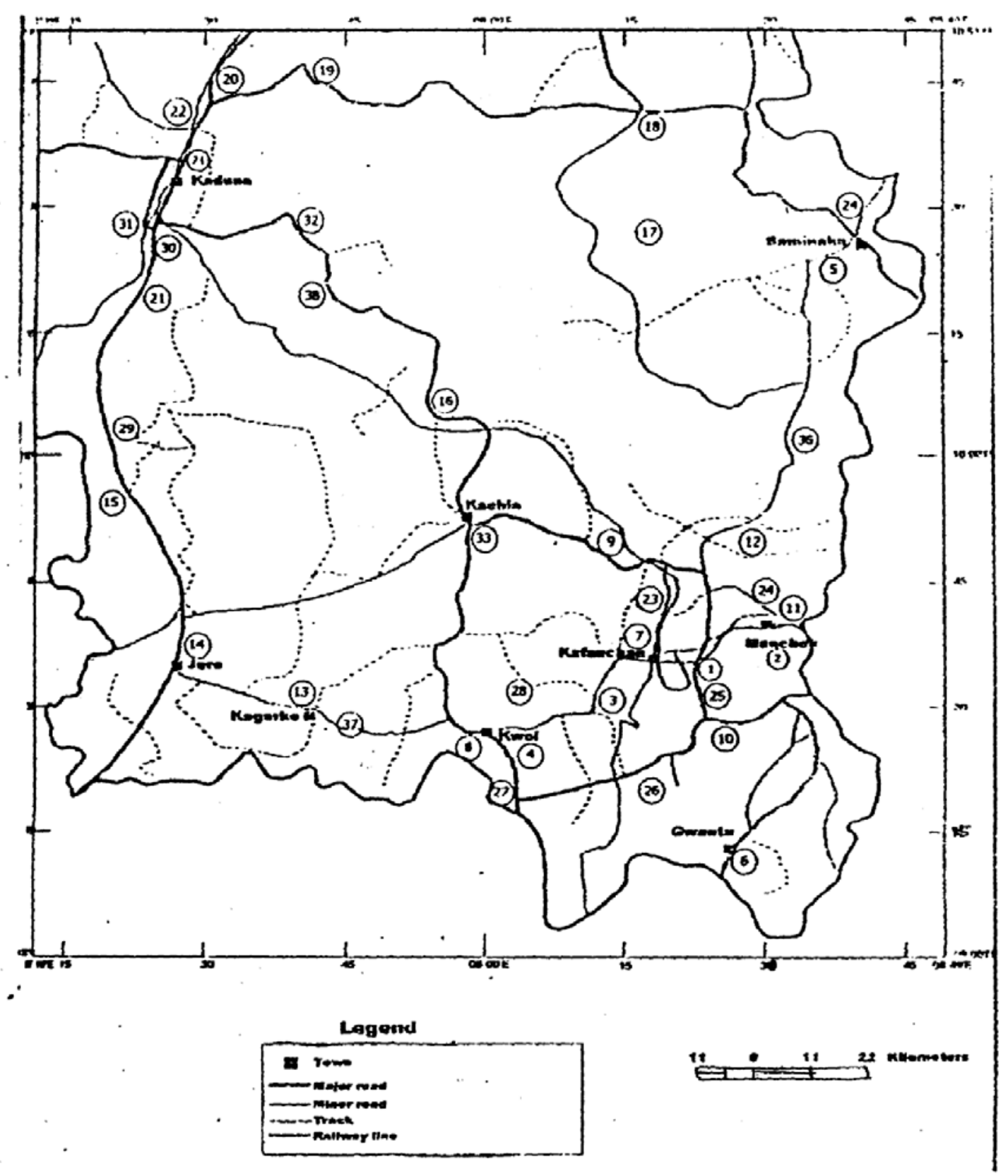

Figure 1. Location Map Showing Sampling Points for Water Analysis

The results of the bacteriological analyses suggest that some of the wells might have been contaminated due to human activities and closeness to pit latrines/soak away and other domestic refuse dumps. Generally, peak values of sanitation pollution indicators (i.e. coliform, nitrates and faecal streptococcus) obtained during the rainy season might be due to high intensity rainfall with mo re possibility of water movement and aided by steep gradient from the source of pollution like the pit latrines and soak-away to hand-dug wells. 


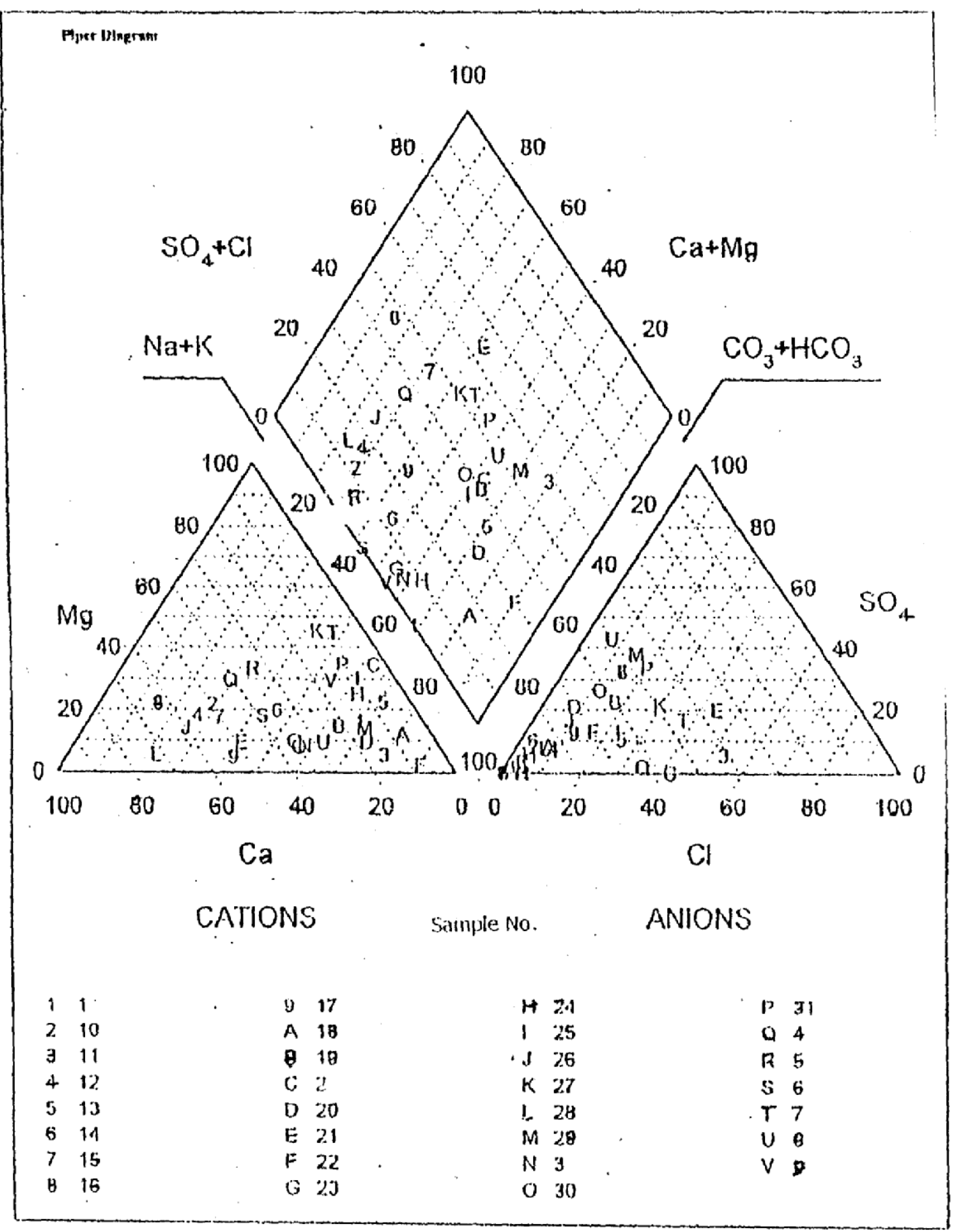

Figure 2. Piper Tri-linear Diagram of Water Samples from the Study Area

\section{Conclusions and Recommendations}

Groundwater from Southern parts of Kaduna State constitutes a major source of water supply to the various communities in the area. The groundwater can be classified as $\mathrm{Ca}-\mathrm{Na}-\mathrm{HCO}_{3}$ fresh water. Results of chemical analyses of water from some of the hand-dug wells suggest that some of the wells might have been contaminated due to human activities and closeness to pit latrines/soak-away and other domestic refuse dumps. It is recommended that hand-dug wells should be lined and constructed far away from any source of possible pollution like pit latrines and soak-away.

\section{REFERENCES}

[1] FMWR (2000). National Water Resource Policy, Dept of Water Supply and Quality Control. Federal Ministry of Water Resources, Abuja. 
[2] Eduvie, M.O. (2004). Exploration, Evaluation and Development of Groundwater in Southern Kaduna State, Nigeria. Ph.D Thesis, Ahmadu Bello Univ., Zaria Nigeria p.247.

[3] Olaniyan, I.O., Agunwamba, J.C. and Ademiluyi, J.O.(2010). Lithologic Characteristics of parts of the crystalline basement complex of northern Nigeria in relation to groundwater exploitation. ARPN Journal of Engineering and Applied Sciences 5(7):56-60, Asian Research Publication Network (ARPN) www.ampjournals.com

[4] Mbonu, M.C. (1989). Contribution to Knowledge Relative to the Hydrogeology of the Basement Rocks of North-Central Nigeria. A Paper Presented at the University Pierre et Marie Gurie, Paris VI, Paris-France.

[5] McCurry, P. (1976). The Geology of the Precambrian to Lower Palaezoic Rocks of Northern Nigeria - A Review. In: Kogbe C.A. (Ed) Geology of Nigeria. Elizabethan Publishers Co., Ibadan, Nigeria pp.15-38.

[6] Egboka, B.C.E. (1988). The Hydrogeological Provinces of Nigeria, Water Quality Bull. 13(4):117-125.

[7] Hazell, J.R.T. Cratchley C.R. and Jones C.R.C. (1992).The Hydrogeology of Crystalline Aquifers in Northern Nigeria and Geophysical Techniques Used in their Exploration. In: Wright, E.P. and Burges, W.G. A Publication of Geological Society Publication No.66.

[8] Jones, M. J. (1985). The Weathered Zone Aquifers of the Basement Complex area of Africa. Q. Journal of Eng. Geology 18:35-46.

[9] MRT Consulting Eng. (Nig) Ltd (1978). Kaduna State Water Board Master Plan 1980-2005. Cambridge, U.K.

[10] Lodadson, I. (1984). Studies on Groundwater Pollution in Kaduna. Final report, Volume 1 and the Appendix to Final Progress Reports. Cumulative Chemical and Microbiological Data, June 1983, and June 1984.

[11] Eduvie, M.O., Mogekwu, E.A. and Adanu, E. A. (1999). Aquifer Assessment and Borehole Characteristics in Parts of Kaduna and Environs. Journal of Water Resources.10 38-45.

[12] Bala, A.E. and Onugba, A. (2001). Preliminary Chemical Assessment of Groundwater in the Basement Complex Area within the Bunsuru and Gagere-sub-basin, Northern Nigeria. Journal of Mining and Geology. Vol. 37, No. 1. Published by the Nigerian Mining and Geosciences Society. 